\title{
POPULATION AND COMPARATIVE BEHAVIOUR OF OCHOTONA ROYLEI AND OCHOTONA MACROTIS IN GOSAINKUNDA AREA, LANGTANG NATIONAL PARK, NEPAL
}

\author{
Narayan P. Koju, Mukesh K. Chalise and Randall C Kyes* \\ Central Department of Zoology \\ Tribhuvan University, Kirtipur, Kathmandu, Nepal \\ "University of Washington, USA
}

\begin{abstract}
Study on the behavior of pika (Ochotona roylei and $O$. macrotis) was carried out during the months of July and August 2011 in Gosainkunda, Langtang National Park (LNP), Nepal. Pika inhabits in the talus habitats of the alpine area. Tharepati (3651 m asl), Phedi (3825 m asl), Gosainkunda (4436 m asl), and Laurebina (3903 m asl) were selected for behavior recording. Quadrates of $50 \mathrm{~m} \times 50 \mathrm{~m}$ were randomly plotted at each site except in Phedi. Only two species of pika were recorded in those areas: Ochotona macrotis was 75 individuals and Ochotona roylei 49 individuals. The ratio of age group adult and infant in $O$. macrotis was $29: 46$ and $O$. roylei $16: 33$ population with density $21 /$ ha and14/ha, respectively. Eleven pikas were observed for $455 \mathrm{~min}$ to record their behaviour from 5:30 AM to 19:30 PM in each day. Feeding, foraging, musing, grooming, chasing each other (playing) were the recorded behavior. They were active at dawn and dusk but were not observed during rainy period. They spent their $26 \%$ of time in feeding, $24 \%$ in musing, $16 \%$ in foraging, and $11 \%$ in grooming. Pikas were observed digging soft rocks, soil and mosses on the rock before discharging pellets.
\end{abstract}

Key words: Ochotona macrotis, Ochotona roylei, behavior, Nepal.

\section{INTRODUCTION}

Pikas are small mammals related to rabbit and hare that inhabit in rocky talus of alpine areas. There are 30 species of Pikas (Ochotona spp.) distributed throughout the world (Hoffmann and Smith 2005). Five species of Pikas have been reported from Nepal viz. Ochotona curzoniae, $O$. nubrica, $O$. thibetana, O. macrotis, O. roylie (IUCN 2011). The Himalayan pika resides between $2500 \mathrm{~m}$ and $5000 \mathrm{~m}$ (Tak and Lamba 1985). They are reported from Sagarmatha National Park, Langtang National Park, Rara National Park, Annapurna Conservation Area and Makalu Barun Conservation Area (Shrestha 2003).
Only large ear pika (Ochotona macrotis) and Royle's pika (Ochotona roylei) are found in Langtang National Park. They both have similar structure and habitat. Molecular study concluded that $O$. macrotis is a sister species of $O$. royle $i$ (IUCN 2011). They have reddish brown fur with pale band over the nape, the winter coat is similar, but may show traces of rufous coloration. Its body length range from $15-20 \mathrm{~cm}$ and the diameter of head is $7 \mathrm{~cm}$, its weights $100-150 \mathrm{~g}$ (Smith et al. 1990). Although, pika shows external activities at night they are frequently active during hours of dawn and dusk (Kawamichi 1971). 


\section{STUDY AREA}

Langtang National Park is located in the central Himalaya of Nepal between $85^{\circ} 15^{\prime}$ E to $86^{\circ} 0^{\prime} \mathrm{E}$ and $28^{\circ} 20^{\prime}$ North. It is at road distance of $132.2 \mathrm{~km}$ from Kathmandu. The park covers 1710 sq $\mathrm{km}$. The shortest highway that connects India and China through Nepal, Pasang Lhamu Highway passes through this National Park. Langtang Lirung (7245 $\mathrm{m}$ ) is the highest point in the park. Langtang National Park was officially established in March 1976. Its land area includes three districts, Rasuwa, Nuwakot, and Sindhupalchowk (DNPWC 2012). The observation was concentrated into four spots of Gosainkunda complex viz Tharepati (N28 00'47.6" E85'29'31.4"), $\quad$ Phedi (N2803'29.9" E85'27'29.8"), Gosainkunda $\left(\mathrm{N} 28^{\circ} 05^{\prime} 38.9^{\prime \prime} \mathrm{E} 85^{\circ} 24^{\prime}\right.$ 22.6") and Laurebina

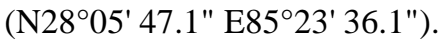

\section{MATERIALS AND METHODS}

Following methods were applied to acquire information on the species.

a) Interview: To acquire the initial information of pika habitat, informal discussion with local people and herders was conducted.

b) Quadrate method: Total fourteen quadrates of $50 \mathrm{~m} \times 50 \mathrm{~m}$ were randomly plotted. Four in Tharepati, two in Phedi (as this is very steep slope with many waterfalls), four in Gosainkunda and four in Laurebina. All the quadrates were plotted above $3500 \mathrm{~m}$ in talus area. The population of pika (direct observation) was recorded thoroughly and behavior was observed within the quadrate. Special morphological features in individual pika like scratch or tears in ears, wart in body, colour and size were taken in account for the continuous recording of individual pika behavior to prohibit repetition in population count and mixed up of individuals' behavior.
Photographs of all observed pika were taken from different angle for identification.

c) Scan sampling: To calculate behavior scan sampling method was applied (Altmann 1974). Behavior of pikas which were not continuously active for less than 15 min was omitted.

\section{RESULTS}

Habitat and ecology: Pikas in Langtang were observed in talus alpine area and forest of Rhododendron, juniper and Abies. $O$. royle $i$ and $O$. macroties, both species of pika were recorded in alpine talus area and $O$. royle $i$ were also recorded in forest. The Royle's pika in forest (forest dweller) was comparatively darker in colour and lives in burrow formed in stones and gap formed by roots of tree. Pika in alpine area inhabited in burrow formed naturally in the gap of rocks. They were found to be herbivorous feeding on different species of the plants and their parts. The leaves, flower and fruits of Fragaria spp and Potentilla spp were consumed. Different plants species under the family Graminae (Poa spp., Denthonia spp. Juncus spp), Primulaceae (Primula spp.) and Polygonaceae (Rumex nepalensis) were common food for them. Some of the pikas were observed feeding in moss and fern.

\section{Population}

In all the studied sites of LNP only two species of pika Ochotona macrotis and Ochotona roylei were recorded (Figs. 1, 2 and 3). Total number of 124 pikas was head counted in which 75 were $O$. macrotis and 49 were $O$. roylei (Table 1 ). The ratio of age group adult and infant in $O$. macrotis is 29:46 and $O$. roylei $16: 33$ population with density 21 individuals per ha and14 individuals per ha, respectively. Among 14 quadrates, no pika were observed in three quadrates; they were one each in Tharepati, Gosainkunda (South of the lake, north facing) and Laurebina (Odar Kharka). 
Table 1. Total population of pika in different quadrates.

\begin{tabular}{|c|c|c|c|c|c|c|}
\hline \multirow{2}{*}{$\begin{array}{l}\text { Quadrate } \\
\text { no. }\end{array}$} & \multicolumn{3}{|c|}{ Population Pika observed } & \multirow{2}{*}{$\begin{array}{l}\text { Coordinate } \\
\text { Location }\end{array}$} & \multirow[t]{2}{*}{ Elevation } & \multirow[t]{2}{*}{ Area/Place } \\
\hline & O. macrotis & O. roylei & Total & & & \\
\hline Q1 & $3(2+1+0)$ & $2(0+2+0)$ & 5 & $\begin{array}{l}\text { N28 } 28^{\circ} 00^{\prime} 47.6^{\prime \prime} \\
\text { E085²9'31.4" }\end{array}$ & $3636 \mathrm{~m}$ & Tharepati \\
\hline Q2 & $1(1+0+0)$ & $2(0+2+0)$ & 3 & $\begin{array}{l}\text { N28ㅇ0'48.4" } \\
\text { E085²9'32.6" }\end{array}$ & $3605 \mathrm{~m}$ & \\
\hline Q3) & $2(1+0+1)$ & $5(2+1+2)$ & 7 & $\begin{array}{l}\text { N28 } 28^{\circ} 02^{\prime} 05.2^{\prime \prime} \\
\text { E085 } 28^{\circ} 53.0^{\prime \prime}\end{array}$ & $3524 \mathrm{~m}$ & \\
\hline Q4 & 0 & 0 & 0 & $\begin{array}{c}\mathrm{N} 28^{\circ} 03^{\prime} 06.1^{\prime \prime} \\
\mathrm{E} 085^{\circ} 28^{\prime} 02.7^{\prime \prime}\end{array}$ & $3634 \mathrm{~m}$ & \\
\hline Q5 & $9(4+3+2)$ & $8(5+3+0)$ & 17 & $\begin{array}{c}\text { N28 } 08^{\circ} 29.9^{\prime \prime} \\
\text { E085²7'29.8" }\end{array}$ & $3764 \mathrm{~m}$ & Phedi \\
\hline Q6 & $5(3+0+2)$ & $4(1+2+1)$ & 9 & $\begin{array}{l}\text { N28 } 28^{\circ} 03^{\prime} 31.2^{\prime \prime} \\
\text { E085²7'53.8" }\end{array}$ & $3764 \mathrm{~m}$ & \\
\hline Q7 & $19(4+9+6)$ & $14(4+8+2)$ & 33 & $\begin{array}{l}\text { N28 } 08^{\circ} 05^{\prime} 38.9^{\prime \prime} \\
\text { E085 } 24^{\circ} 22.6^{\prime \prime}\end{array}$ & $4423 \mathrm{~m}$ & Gosainkunda \\
\hline Q8 & $6(3+2+1)$ & $1(0+1+0)$ & 7 & $\begin{array}{c}\text { N28 } 28^{\circ} 05^{\prime} 02.2^{\prime \prime} \\
\text { E085² } 24^{\prime} 37.6^{\prime \prime}\end{array}$ & $4436 \mathrm{~m}$ & \\
\hline Q9 & $9(4+0+5)$ & $5(2+1+2)$ & 14 & $\begin{array}{l}\text { N28 } 28^{\circ} 06^{\prime} 04.7^{\prime \prime} \\
\text { E085²4'42.8" }\end{array}$ & $4404 \mathrm{~m}$ & \\
\hline Q10 & 0 & 0 & 0 & $\begin{array}{l}\text { N28 } 08^{\circ} 06^{\prime} 54.7^{\prime \prime} \\
\text { E085²2'42.8" }\end{array}$ & $4324 \mathrm{~m}$ & \\
\hline Q11 & $13(4+6+3)$ & $5(2+1+2)$ & 18 & $\begin{array}{l}\text { N28 } 08^{\circ} 05^{\prime} 23.1^{\prime \prime} \\
\text { E085²2'56.9" }\end{array}$ & $3951 \mathrm{~m}$ & Laurebina \\
\hline Q12 & $5(1+4+0)$ & $3(0+2+1)$ & 8 & $\begin{array}{l}\text { N28 } 08^{\circ} 05^{\prime} 47.1^{\prime \prime} \\
\text { E085 } 23^{\prime} 36.1^{\prime \prime}\end{array}$ & $3916 \mathrm{~m}$ & \\
\hline Q13 & $\begin{array}{r}\text { only old pelle } \\
\text { pik }\end{array}$ & $\begin{array}{l}\text { unidentified } \\
\text { ere observed }\end{array}$ & ecies of & $\begin{array}{l}\text { N28 } 28^{\circ} 05^{\prime} 12.3^{\prime \prime} \\
\text { E085²3'25.2" }\end{array}$ & $3951 \mathrm{~m}$ & Odhar Khark \\
\hline Q14 & $3(2+1+0)$ & 0 & 3 & $\begin{array}{l}\text { N28 } 28^{\circ} 05^{\prime} 48.9^{\prime \prime} \\
\text { E085 } 23^{\prime} 0.5^{\prime \prime}\end{array}$ & $3879 \mathrm{~m}$ & Barna goath \\
\hline Total & 75 & 49 & 124 & & & \\
\hline
\end{tabular}

\section{General behavior}

Behavior recorded during this study includes Musing: Motionless or just resting on the big stone for shorter or longer time; Feeding: Eating grass, flower or other parts of plant; Foraging: the movement for searching and selecting food; Groom: the process of cleaning body and fur; Calling: Making sound; Galloping: Jumping from one rock to other rock or in the ground; Chasing: playing behavior recorded among infants at evening time; Inside burrow: Pika enters burrow and use number of burrows for short time while foraging and feeding were recorded.
Behavior of pika was observed from 5:30 am to $19: 30 \mathrm{pm}$ for ten days. It took $103 \mathrm{~h}$ and $35 \mathrm{~min}$ field work to acquire behavioral data of eleven pikas (six O. macrotis and five $O$. roylei). The total contact time for the observation was $455 \mathrm{~min}$ that was seven hour and thirty five min. They were one (O. rolyei) in Tharepati $(3651 \mathrm{~m})$, three (one $O$. macrotis and two $O$. rolyei) in Phedi $(3825 \mathrm{~m})$, four $O$. macrotis in Gosainkunda (4436 m), two $O$. rolyei in Laurebiana $3903 \mathrm{~m}$ and one O. marcotis in Barna Goth 3879 m. Pikas were active during dawn and dusk. They were not active outside and even not seen in rainy period. Very few infants 
were seen at the day time. They were active and fast moving. They use numbers of burrows while foraging and feeding. Behavior of pika was recorded in the interval of one min.

The observed activities for both species pika were $455 \mathrm{~min}$. Among them, O. macrotis was observed for $205 \mathrm{~min}$ and $O$. roylei was $250 \mathrm{~min}$ (Table 2). In average they spent more time in feeding (26.37\%), musing (23.96\%), inside burrow $(16.04 \%)$ while least time spent in chasing $(0.88 \%)$ and galloping (1.98\%). However, in both pika species difference was observed in different

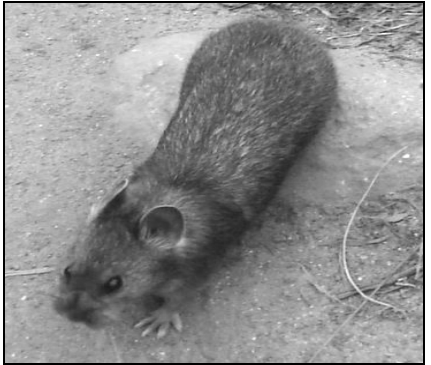

(a) O. roylei behaviours. The highest percentage of time spent by $O$. roylei during observation (250 $\mathrm{min}$ ) was on musing $(25.2 \%)$ then comes feeding $(20.8 \%)$ and inside burrow (19.2\%) while the least time was spent in chasing $(1.6 \%)$. The chasing behavior was observed only in five juvenile pikas during the evening period. In $O$. macrotis species the observation recorded highest in feeding $(33.17 \%)$, then musing $(22.44 \%)$ and foraging $(15.12 \%)$. The least time for galloping behavior $(1.46 \%)$ was observed while there was no record of chasing.

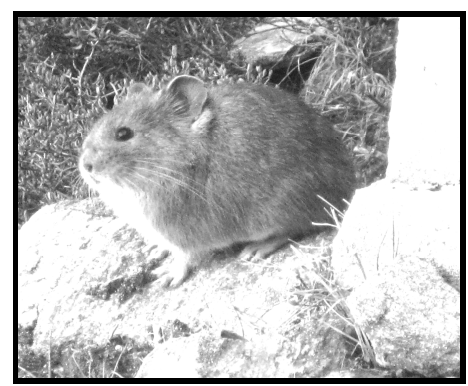

(b) O. macrotis

Fig. 1. Two species of Pika recorded in the study area.

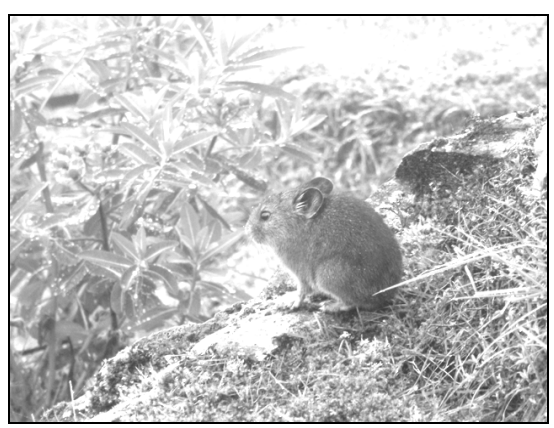

Fig. 2. Infant $O$. roylei

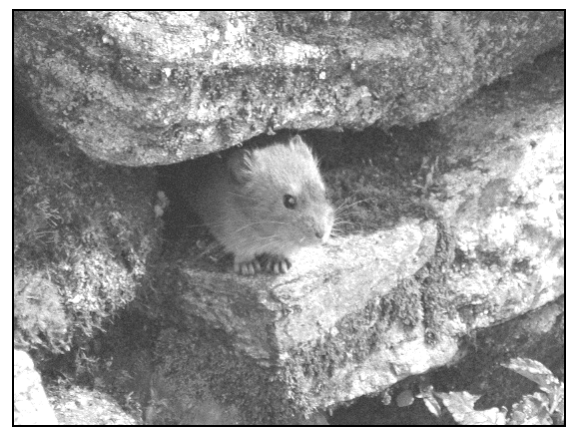

Fig. 3. Infant of $O$. macrotis

Table 2. Total time budget of two species of pika in Langtand National Park.

\begin{tabular}{llccc}
\hline SN & Behaviour & \multicolumn{2}{c}{ Time in mins and respective (\%) } & Total time \\
& & O. roylei & o. macrotis & $120(26.37)$ \\
\hline 1 & Feeding & $52(20.8)$ & $68(33.17)$ & $72(15.82)$ \\
2 & Foraging & $41(16.4)$ & $31(15.12)$ & $73(16.04)$ \\
3 & Inside burrow & $48(19.2)$ & $25(12.19)$ & $51(11.21)$ \\
4 & Grooming & $29(11.6)$ & $22(10.73)$ & $109(23.96)$ \\
5 & Musing & $63(25.2)$ & $46(22.44)$ & $17(3.74)$ \\
6 & Calling & $07(2.8)$ & $10(4.88)$ & $9(1.98)$ \\
7 & Galloping & $06(2.4)$ & $03(1.46)$ & $4(0.88)$ \\
8 & Chasing & $04(1.6)$ & 0 & $455(100 \%)$ \\
\hline
\end{tabular}


Calling behavior is of two types: long call 'Chirr....r' (produced while musing) and short call 'chin chin' (produced during chasing). In the Phedi area only long calling was heard/observed and it was only in $O$. marcotis species. These pikas were feeding on the big stone and exchanging long calls. Musing behavior was observed in all pikas. They performed short musing (less than one min) and long musing (more than five min in a time). They entered burrow for few second to less than five min while feeding and foraging. Pikas groom their bodies and furs with hind limbs, sometime mouth and fore limb are also used. Both species were observed stretching their body after long musing or grooming. Every individual species was observed musing and grooming

Some infant pikas were observed discharging pellets outside the burrow. This behavior was recorded both in morning and evening trips. They dig on soft rock or rock mosses for few min by fore limbs before discharging pellets. Only single pika was observed transporting green plants into its burrow in rainy season. The synanthropic tendency is distinct in Ochotona roylei. Two Ochotona roylei were observed inside the home of local people in Gosainkunda and a Royle's Pika was also observed stealing green leaf (vegetable) from hotel's kitchen garden in Laurebina.

Table 3. Information of dead pika.

\begin{tabular}{|c|c|c|}
\hline $\begin{array}{l}\text { Parti- } \\
\text { cular }\end{array}$ & $\begin{array}{l}\text { Measure- } \\
\text { ment }\end{array}$ & $\begin{array}{l}\text { Weather: Raining } \\
\text { Temperature: } 7^{\circ} \mathrm{C} \\
\text { Slope face: NW }\end{array}$ \\
\hline Species & O. roylei & \\
\hline $\begin{array}{l}\text { Body } \\
\text { length }\end{array}$ & $150 \mathrm{~mm}$ & \\
\hline $\begin{array}{l}\text { Head } \\
\text { length }\end{array}$ & $51 \mathrm{~mm}$ & \\
\hline $\begin{array}{l}\text { Hind } \\
\text { limb }\end{array}$ & $67 \mathrm{~mm}$ & \\
\hline $\begin{array}{l}\text { Fore } \\
\text { limb }\end{array}$ & $54 \mathrm{~mm}$ & \\
\hline $\begin{array}{l}\text { Ear } \\
\text { (pinna) }\end{array}$ & $26 \mathrm{~mm}$ & \\
\hline Weight & $152 \mathrm{gms}$ & \\
\hline Sex & male & \\
\hline
\end{tabular}

A dead pika was found in quadrate (Q2) in Tharepati (Table 3). It was about a week of death lying near the burrow. It was a male of $O$. royle $i$ with body length of $150 \mathrm{~mm}$, head length $51 \mathrm{~mm}$ and weight $150 \mathrm{gm}$ and was found $72 \mathrm{~m}$ west of the hotel building. According to local respondent sometime pika were killed by children for fun. They use stone and catapult for killing purposes.

\section{DISCUSSION}

Bhattacharya et al. (2009) recorded mean density of royle's pika 15.3 individual per hectare in Uttarkhanda, Western India. Similarly Smith et al. (1990) found the density of Royle's pika 12.5 per hectare individuals in Nepal. The population observed in this study is less than Indian population density and more than Smith's report. The population of pika reported by Khatiwada (2004), 350 individuals per hectare in Langtang is very high figure in comparison to other researches. As that research seems to be extra effort during snow leopard study so proper attention of habitat and pika behavior were not taken into consideration. Kawamichi (1968) reported Pika in Gosainkunda do not make high and sharp call. He heard only very weak cries in winter season but in this study of rainy season two types of calling was recorded, calling in $O$. rolyei is less sharp than $O$. macrotis and six among eleven pikas were observed making call. Pikas are famous for their characteristic calls, they make calling for communication.

The synanthropic tendency is distinct in $O$. roylei (Kawamichi 1968). He reported, at Dewche village, they live within native houses, walls of which are made by a heap of rocks. They run through the interspaces of walls and their excrement is found on shelves in the sitting-room. Their daily life is spent in and around the houses, probably rather independent from natural conditions. Such trait was not observed in $O$. macrotis at Periche village. A few natives in 
Dingboche, a village within the range of macrotis, told to the author that "Thyapo" (local name of pika) carried away potatoes and stalks and grains of wheat stored in their houses (Kawamichi 1971). In our observation $O$. royle $i$ and $O$ macrotis had similar behavior as Kawamichi observed in Dingboche, Sagarmatha National Park but behavior reported by local people about $O$. macrotis was not observed in Gosainkunda route. Abe (1971) reported presence of three species in Gosainkunda region but as other researchers (Bishwas and Khajuria 1955, Deo et al. 2009, Kawamichi 1968) and we confirmed only two species currently.

\section{ACKNOWLEDGEMENTS}

We are grateful to DNPWC/Nepal for the field permission and to Prof. Andrew T. Smith, IUCN/SSC Lagomorphs Specialist Group, Arizona State University, Prof. Dr. Taeko Kawamichi, Kyoto University, and Prof. Chris Ray, Colorado University for providing us literature and valuable suggestion. We like to thank H.K. Dongol and R. Chawal, for the support in the field work.

\section{REFERENCES}

Abe, H. 1971. Small Mammals of Central Nepal. J. Fac. Agr. Hokkaido University, Japan, Sapporo, 56:403-406.

Altmann, J. 1974. Observational study of behavior: sampling methods. Behaviour 49:227-265.

Bhattacharyya, S., B.S. Adhikari and G.S. Rawat. 2009. Abundance of royale's pika (Ochotona roylei) along an altitudinal gradient in Uttarakhand, Western Himalaya. Hystrix It J. Mamm. pp. 111-119.

Biswas, B. and H. Khajuria. 1955. Zoological results of the 'Daily Mail' Himalayan expedition,1954, Four new mammals from Khumbu, eastern Nepal. Proc. of the Zoological Society of Calcutta 8:26-29.
Deo, R.K., H.K. Shrestha, B. Khanal and S. Devkota. 2008. A Study Vulnerability Assessment and Formulation of Climate Change Adaptation Strategies for Langtang National Park and Buffer Zone. Socioeconomic, Agro-Forestry and Environment (SAFE), Kathmandu, Nepal. pp. 13-53

DNPWC. 2012. http://www.dnpwc.gov.np/protectedareas/national-parks/7-langtang-national-park.html, November 27.

Hoffmann, R.S. and A.T. Smith. 2005. Oder lagomorphs. In: Mammals Species of the World. (eds.) Wilson, D.E. and D.M. Reeder. Johns Hopkins University Press, Baltimore, USA. pp. 185-211.

IUCN. 2011. IUCN Red List of Threatened Species. Version 2011.2. 〈www.iucnredlist.org>.

Kawamichi, T. 1968. Winter behaviour of the Himalayan Pika (Ochotona roylei). J. Fac. Sci. Hakkaido University, Ser. VI. Zool. 16:552554.

Kawamichi, T. 1971. Daily activities and social pattern of two Himalayan Pikas, Ochotona marcrotis and Ochotona roylei observed at Mt. Everest. J. Fac. Sci., Hokkaido University, Japan, VI, Zool. 17:587-609.

Khatiwada, J.R. 2004. The status of snow leopard and its conflict perception in Langtang National Park. M.Sc. Thesis, Central Department of Zoology, Tribhuvan University, Kirtipur, Kathmandu, Nepal.

Shrestha, T.K. 2003. Wildlife of Nepal. Tribhuvan University, Curriculum Center, Kathmandu. pp. 251-253.

Smith, A.T., N. Formozov, R.S. Hoffmann, Z. Changlin and M.A. Erbajena. 1990. The Pika Accounts of Genera and Species, Rabbits, Hares and Pikas. Status Survey and Conservation Action Plan. Chapter 3, IUCN, Gland, Switzerland.

Tak, P.C. and B.S. Lamba. 1985. Nanda Devi National Park: A contribution to its mammalogy. Indian Journal of Forestry 8:219-230. 